\title{
Predicting percentage body fat through waist-to-height ratio (WtHR) in Spanish schoolchildren
}

\author{
MD Marrodán 1,2,* , JR Martínez Álvarez ${ }^{1,2}$, M González-Montero de Espinosa ${ }^{1}$, \\ MM Carmenate ${ }^{3}, \mathrm{~N}$ López-Ejeda ${ }^{1}$, MD Cabañas ${ }^{1}, \mathrm{JL}_{\text {Pacheco }}{ }^{1}, \mathrm{MS}$ Mesa ${ }^{1}$, \\ JF Romero-Collazos ${ }^{1,3}, \mathrm{C} \mathrm{Prado}^{3}$ and A Villarino ${ }^{1,2}$ \\ 'Dpto. de Zoología y Antropología Física, Facultad de Biología, Research Group EPINUT, Complutense University \\ of Madrid, c/ José Antonio Novais 2, 28891 Madrid, Spain: ${ }^{2}$ Spanish Diet and Food Science Association, \\ Madrid, Spain: ${ }^{3}$ Biology Department, Faculty of Sciences Autónoma University of Madrid, Madrid, Spain
}

Submitted 26 April 2012: Final revision received 31 January 2013: Accepted 13 February 2013: First published online 28 March 2013

\begin{abstract}
Objective: To analyse the association between waist-to-height ratio (WtHR) and body fat and to develop predictive adiposity equations that will simplify the diagnosis of obesity in the paediatric age group.

Design: Cross-sectional study conducted in Spain during 2007 and 2008. Anthropometric dimensions were taken according to the International Biology Program. The children were classified as underweight, normal weight, overweight or obese according to national standards of percentage body fat (\%BF). WtHR differences among nutritional status categories were evaluated using ANOVA. Correlation analysis and regression analysis were carried out using WtHR as a predictor variable for \%BF. A $t$ test was applied to the results obtained by the regression model and by the Siri equation. The degree of agreement between both methods was evaluated by estimating the intra-class correlation coefficient.

Setting: Elementary and secondary schools in Madrid (Spain).

Subjects: Girls ( $n$ 1158) and boys ( $n$ 1161) from 6 to 14 years old.

Results: WtHR differed significantly $(P<0 \cdot 001)$ depending on nutritional status category. This index was correlated $(P<0 \cdot 001)$ with all adiposity indicators. The mean \%BF values estimated by the regression model (boys: $\% \mathrm{BF}=106 \cdot 50 \times$ WtHR-28.36; girls: $\% \mathrm{BF}=89 \cdot 73 \times \mathrm{WtHR}-15 \cdot 40)$ did not differ from those obtained by the Siri equation. The intra-class correlation coefficient $(0.85$ in boys, 0.79 in girls) showed a high degree of concordance between both methods.

Conclusions: WtHR proved to be an effective method for predicting relative adiposity in 6-14-year-olds. The developed equations can help to simplify the diagnosis of obesity in schoolchildren.
\end{abstract}

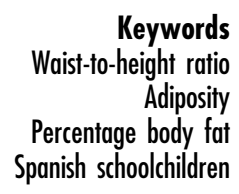

Throughout infancy and adolescence, just as in adulthood, waist circumference (WC) is significantly correlated to $\mathrm{BMI}$ and to percentage body fat $(\% \mathrm{BF})^{(1,2)}$. Studies carried out on a wide range of boys and girls of different ethnic origin have revealed a clear association between this circumference and serum concentrations of lipids, insulin and glycaemic index ${ }^{(3,4)}$. Thus, it is considered a good indicator of abdominal obesity and a prognostic factor for the metabolic syndrome in the child and adolescent population $^{(5,6)}$.

Nevertheless, the diagnostic use of WC has diminished due to it being a variable that increases throughout growth, thus requiring comparison of an individual's value with percentile standards for sex and age. Furthermore, published standards reflect some ethnic variability, demonstrating the importance of choosing an appropriate reference, since the diagnosis can vary according to the reference applied ${ }^{(7-9)}$. On the contrary, the quotient between WC and height, also known as waist-to-height ratio (WtHR), eliminates the need to compare with percentile standards since it remains stable throughout growth ${ }^{(10)}$.

Furthermore, recent studies have shown that WtHR is more successful at detecting and predicting metabolic risk in children and adolescents than other anthropometric dimensions such as WC, BMI or the sum of triceps and subscapular skinfolds ${ }^{(11-13)}$. WtHR, as compared with BMI, is also more tightly associated with a larger left ventricle $^{(14)}$ and even with the presence of depression in children and adolescents with excess weight ${ }^{(15)}$.

A WtHR higher than 0.50 is considered to be an indicator of central obesity in adults ${ }^{(16,17)}$. This figure has 
also been used in the child and adolescent population $^{(13,18)}$. Although WtHR is primarily a reflection of abdominal fat, it is interesting to know the relationship it has to other total or relative adiposity estimators. Working with a large sample of Australian schoolchildren, Nambiar et al. found that WtHR is very useful to identify individuals with a high percentage of fat ${ }^{(19)}$. The same conclusion was reached by the authors of the present work, after applying the method of ROC (receiveroperating characteristic) curves in the Spanish infant population $^{(20)}$. With this background, the aim of present study was to deepen the analysis of the association between WtHR and body fat, from 6 to 14 years of age, with the goal of developing predictive equations for adiposity which will simplify the diagnosis of overweight and obesity in schoolchildren.

\section{Methodology}

A total of 2319 schoolchildren (1158 boys and 1161 girls) between the ages of 6 and 14 years were analysed. Data collection was carried out in 2007 and 2008 in elementary and secondary schools in the city of Madrid (Spain) and as part of a project financed by the Ministry of Education and Science of the Spanish Government (GGL-2005-03752). The boys and girls of the sample had parents and grandparents born in different Spanish regions. According to the profession and studies of the parents $(28.93 \%$ college, $31.07 \%$ with secondary education or professional training, $40.00 \%$ with primary education), socio-economic status was considered medium.

Once parental or guardian written informed consent was obtained, respecting the Helsinki Declaration ${ }^{(21)}$, each of the participating boys and girls was measured with approved materials and according to International Biology Program regulations ${ }^{(22)}$. Anthropometric dimensions included weight $(\mathrm{kg})$, height $(\mathrm{cm}), W C(\mathrm{~cm})$ and biceps, triceps, subscapular and suprailiac skinfolds (mm). Sum of four skinfolds, WtHR (WC divided by height), BMI (weight in kilograms divided by the square of height in metres) and \%BF (from the direct measurements of skinfold thickness) were calculated. In the last case, the Siri equation was used ${ }^{(23)}$, previously estimating the density by means of Brook ${ }^{(24)}$ or Durnin and Rahaman ${ }^{(25)}$ equations in accordance with sex and age. Subsequently, the children were classified according to adiposity percentile (P) standards for the Spanish child population, published by Marrodán et $a l^{(26)}$ : underweight $(\% \mathrm{BF} \leq \mathrm{P} 10)$, adequate weight ( $\% \mathrm{BF}>\mathrm{P} 10$ to $<\mathrm{P} 90)$, overweight $(\% \mathrm{BF} \geq \mathrm{P} 90$ to $<$ P97) and obese (\%BF $\geq$ P97).

Anthropometric assessments were performed by members of the research team, each highly trained and accredited (third and fourth level) by the International Society for the Advancement of Kinanthropometry ${ }^{(27)}$. Technical errors of measurement (TEM; intra-evaluator and inter-evaluator) were estimated according to Pederson and Gore's methodology ${ }^{(28)}$. Both absolute and relative TEM were in the tolerance margins recommended by the International Society for the Advancement of Kinanthropometry for all measures and anthropometrists ${ }^{(27)}$. The lowest values corresponded to weight (TEM intra: $1.2 \%$; inter TEM: $0.4 \%)$ and the highest values to suprailiac skinfold (TEM intra: $1 \cdot 87 \%$; inter TEM: $1 \cdot 22 \%$ ). This procedure ensures the validity and reliability of anthropometric measurements.

Sex and age differences in anthropometric data were assessed using the Student's $t$ test or ANOVA. In the same way, ANOVA was used to evaluate WtHR differences among the four established nutritional status categories based on \%BF. Pearson correlation coefficients were estimated among BMI, sum of skinfolds, \%BF, WC and WtHR. In order to determine whether individuals falling within the high body fat category were likely to have higher WtHR than those with lower body fat, binary logistic regression analysis was run considering as dependent variable the presence of central obesity (WtHR $\geq 0.5$ ) including body fat categories (overweight and obesity), age and sex as independent variables.

A linear regression analysis was carried out using WtHR as the predictor variable and $\% \mathrm{BF}$ as the dependent variable. In order to validate the prediction equations a Student $t$ test for paired samples was carried out by comparing the $\% \mathrm{BF}$ obtained using the Siri formula and the \%BF obtained using the model. Furthermore, agreement between both expressions was calculated using the intra-class correlation coefficient (ICC) ${ }^{(29)}$. The statistical software package SPSS version $19 \cdot 0$ was used for statistical analysis.

\section{Results}

Table 1 provides summary statistics for anthropometric variables by age categories, in boys and girls. Among ages 6 to 14 years, all anthropometric dimensions showed significant changes $(P<0 \cdot 001)$ except for WtHR, which remained stable throughout the growth period analysed. On the other hand, boys were generally taller than girls except at age 12 years when girls were $2.35 \mathrm{~cm}$ taller than boys $(P<0 \cdot 05)$. Also, girls had higher skinfold thicknesses and \%BF from 12 years old $(P<0 \cdot 001)$.

Table 2 shows, in both sexes, that WtHR differed significantly $(P<0 \cdot 001)$ depending on nutritional status category established according to adiposity standards. The mean WtHR values for the overweight and obesity categories were higher in the feminine series. By analysing the correlation among anthropometric variables related to total or abdominal fat, Pearson's $r$ coefficients proved to be significant in all cases (Table 3). However, contrary to what happened with WC, WtHR was more closely associated with sum of skinfolds and \%BF than with BMI. Logistic regression confirmed the association 
Table 1 Summary statistics for anthropometric variables; boys and girls aged 6-14 years, Madrid, Spain, 2007-2008

\begin{tabular}{|c|c|c|c|c|c|c|c|c|c|c|}
\hline Sex/Age & Weight $(\mathrm{kg})$ & Height $(\mathrm{cm})$ & WC $(\mathrm{cm})$ & $\mathrm{TS}(\mathrm{mm})$ & $\mathrm{BS}(\mathrm{mm})$ & SBS (mm) & SPS (mm) & WtHR & BMI $\left(\mathrm{kg} / \mathrm{m}^{2}\right)$ & $\% B F$ \\
\hline \multicolumn{11}{|l|}{ Boys } \\
\hline \multicolumn{11}{|c|}{6 years $(n 119)$} \\
\hline Mean & $23 \cdot 28$ & $118 \cdot 33$ & $52 \cdot 21$ & $8 \cdot 1$ & $4 \cdot 2$ & $4 \cdot 7$ & $5 \cdot 3$ & 0.45 & $16 \cdot 53$ & $15 \cdot 50$ \\
\hline SD & $4 \cdot 38$ & $5 \cdot 88$ & $4 \cdot 33$ & $2 \cdot 2$ & $1 \cdot 1$ & $1 \cdot 4$ & $1 \cdot 2$ & 0.03 & $2 \cdot 12$ & $3 \cdot 31$ \\
\hline \multicolumn{11}{|c|}{7 years $(n 109)$} \\
\hline Mean & $22 \cdot 94$ & $123 \cdot 25$ & $54 \cdot 28$ & $6 \cdot 7$ & $3 \cdot 8$ & $4 \cdot 3$ & $5 \cdot 1$ & 0.45 & $15 \cdot 11$ & $14 \cdot 08$ \\
\hline SD & $1 \cdot 37$ & $3 \cdot 76$ & 1.72 & 1.5 & 0.6 & 0.3 & $1 \cdot 3$ & 0.01 & 0.83 & $1 \cdot 70$ \\
\hline \multicolumn{11}{|c|}{8 years $(n 120)$} \\
\hline Mean & $28 \cdot 05$ & $129 \cdot 15$ & $58 \cdot 25$ & 8.5 & $4 \cdot 3$ & $5 \cdot 0$ & $5 \cdot 2$ & 0.45 & $16 \cdot 76$ & $15 \cdot 67$ \\
\hline SD & $3 \cdot 84$ & $6 \cdot 10$ & $2 \cdot 97$ & $2 \cdot 8$ & $1 \cdot 2$ & 1.5 & $1 \cdot 7$ & 0.02 & $1 \cdot 36$ & $4 \cdot 34$ \\
\hline \multicolumn{11}{|c|}{9 years $(n 165)$} \\
\hline Mean & $32 \cdot 48$ & $137 \cdot 00$ & $62 \cdot 12$ & $10 \cdot 7$ & $6 \cdot 8$ & $8 \cdot 1$ & $9 \cdot 7$ & 0.45 & $17 \cdot 23$ & $20 \cdot 93$ \\
\hline SD & $7 \cdot 10$ & $6 \cdot 05$ & $7 \cdot 72$ & $4 \cdot 4$ & $3 \cdot 2$ & $5 \cdot 1$ & $4 \cdot 2$ & 0.05 & 3.07 & $7 \cdot 78$ \\
\hline \multicolumn{11}{|c|}{10 years $(n 128)$} \\
\hline Mean & $37 \cdot 93$ & $141 \cdot 20$ & $65 \cdot 32$ & $11 \cdot 5$ & $7 \cdot 4$ & $9 \cdot 3$ & $10 \cdot 8$ & 0.46 & $19 \cdot 01$ & $22 \cdot 08$ \\
\hline $\mathrm{SD}$ & 9.02 & $6 \cdot 61$ & $6 \cdot 49$ & $5 \cdot 2$ & $4 \cdot 1$ & $6 \cdot 0$ & $4 \cdot 8$ & 0.05 & $3 \cdot 84$ & $8 \cdot 26$ \\
\hline \multicolumn{11}{|c|}{11 years $(n 100)$} \\
\hline Mean & $41 \cdot 00$ & $145 \cdot 94$ & $67 \cdot 30$ & $11 \cdot 9$ & $7 \cdot 8$ & $9 \cdot 1$ & $11 \cdot 1$ & 0.45 & $19 \cdot 09$ & $22 \cdot 86$ \\
\hline SD & $9 \cdot 04$ & $7 \cdot 23$ & $8 \cdot 68$ & $4 \cdot 6$ & $3 \cdot 2$ & $5 \cdot 4$ & $4 \cdot 6$ & 0.04 & 3.03 & $7 \cdot 55$ \\
\hline \multicolumn{11}{|c|}{12 years $(n 116)$} \\
\hline Mean & $45 \cdot 10$ & $150 \cdot 02$ & $69 \cdot 10$ & $11 \cdot 4$ & $7 \cdot 1$ & $9 \cdot 2$ & $11 \cdot 7$ & 0.46 & $19 \cdot 84$ & $19 \cdot 40$ \\
\hline SD & $10 \cdot 88$ & $8 \cdot 28$ & $9 \cdot 72$ & $5 \cdot 1$ & $3 \cdot 7$ & $6 \cdot 5$ & $4 \cdot 8$ & 0.05 & 3.46 & 6.59 \\
\hline \multicolumn{11}{|c|}{13 years $(n 107)$} \\
\hline Mean & $49 \cdot 72$ & $157 \cdot 80$ & $69 \cdot 52$ & $10 \cdot 5$ & $6 \cdot 6$ & $8 \cdot 8$ & $9 \cdot 9$ & 0.44 & $19 \cdot 86$ & $18 \cdot 17$ \\
\hline SD & $10 \cdot 04$ & $7 \cdot 32$ & $7 \cdot 85$ & $5 \cdot 2$ & $3 \cdot 4$ & $5 \cdot 4$ & $4 \cdot 4$ & 0.04 & $3 \cdot 19$ & 5.96 \\
\hline \multicolumn{11}{|c|}{14 years $(n 194)$} \\
\hline Mean & $55 \cdot 91$ & $164 \cdot 31$ & $72 \cdot 27$ & $10 \cdot 5$ & $6 \cdot 8$ & $9 \cdot 6$ & $11 \cdot 3$ & 0.44 & $20 \cdot 60$ & $19 \cdot 10$ \\
\hline SD & $10 \cdot 18$ & $7 \cdot 90$ & $7 \cdot 33$ & $5 \cdot 7$ & $4 \cdot 0$ & $5 \cdot 3$ & $5 \cdot 4$ & 0.04 & $3 \cdot 21$ & $5 \cdot 85$ \\
\hline ANOVA & $F=66 \cdot 07$ & $F=179 \cdot 1$ & $F=20 \cdot 8$ & $F=3 \cdot 10$ & $F=4 \cdot 62$ & $F=6.62$ & $F=3.05$ & NS & $F=11 \cdot 04$ & $F=7 \cdot 67$ \\
\hline & $P<0.001$ & $P<0.001$ & $P<0.001$ & $P<0.05$ & $P<0.001$ & $P<0.001$ & $P<0.05$ & & $P<0.001$ & $P<0.001$ \\
\hline \multicolumn{11}{|l|}{ Girls } \\
\hline \multicolumn{11}{|c|}{6 years $(n 117)$} \\
\hline Mean & $23 \cdot 44$ & $120 \cdot 25$ & $52 \cdot 37$ & $9 \cdot 9$ & 4.9 & $5 \cdot 3$ & $6 \cdot 4$ & 0.45 & $16 \cdot 15$ & $14 \cdot 94$ \\
\hline SD & $3 \cdot 70$ & $6 \cdot 21$ & $4 \cdot 17$ & $2 \cdot 5$ & $1 \cdot 2$ & $1 \cdot 0$ & $1 \cdot 7$ & 0.02 & $1 \cdot 66$ & $3 \cdot 71$ \\
\hline \multicolumn{11}{|c|}{7 years $(n 125)$} \\
\hline Mean & $24 \cdot 52$ & $123 \cdot 78$ & $54 \cdot 73$ & $9 \cdot 3$ & $5 \cdot 2$ & $5 \cdot 0$ & $6 \cdot 0$ & 0.44 & $15 \cdot 87$ & $13 \cdot 89$ \\
\hline SD & 3.67 & $5 \cdot 96$ & $3 \cdot 60$ & $2 \cdot 6$ & $1 \cdot 7$ & $1 \cdot 1$ & $1 \cdot 6$ & 0.02 & $1 \cdot 51$ & $4 \cdot 57$ \\
\hline \multicolumn{11}{|c|}{8 years $(n 125)$} \\
\hline Mean & $28 \cdot 89$ & $129 \cdot 66$ & $58 \cdot 38$ & $11 \cdot 4$ & $6 \cdot 9$ & $6 \cdot 5$ & $6 \cdot 9$ & 0.45 & $17 \cdot 11$ & $17 \cdot 41$ \\
\hline SD & $4 \cdot 48$ & $5 \cdot 78$ & $4 \cdot 60$ & $3 \cdot 2$ & $2 \cdot 3$ & $2 \cdot 6$ & $2 \cdot 7$ & 0.06 & 1.97 & $5 \cdot 88$ \\
\hline 9 years & & & & & & & & & & \\
\hline Mean & $32 \cdot 48$ & $135 \cdot 13$ & $60 \cdot 90$ & $11 \cdot 9$ & $7 \cdot 3$ & $8 \cdot 9$ & $10 \cdot 2$ & 0.45 & $17 \cdot 63$ & $20 \cdot 36$ \\
\hline SD & $7 \cdot 19$ & $6 \cdot 24$ & $7 \cdot 62$ & $4 \cdot 6$ & $3 \cdot 5$ & $5 \cdot 5$ & $6 \cdot 2$ & 0.04 & $2 \cdot 78$ & 8.99 \\
\hline 10 years & & & & & & & & & & \\
\hline Mean & $37 \cdot 36$ & $141 \cdot 82$ & $64 \cdot 05$ & $12 \cdot 8$ & $7 \cdot 9$ & $9 \cdot 8$ & $10 \cdot 8$ & 0.45 & $18 \cdot 44$ & $22 \cdot 18$ \\
\hline SD & $7 \cdot 85$ & $7 \cdot 26$ & $8 \cdot 01$ & $4 \cdot 1$ & $3 \cdot 0$ & $5 \cdot 5$ & $6 \cdot 6$ & 0.05 & $2 \cdot 88$ & $7 \cdot 94$ \\
\hline 11 years & & & & & & & & & & \\
\hline Mean & $42 \cdot 15$ & $146 \cdot 09$ & $65 \cdot 94$ & $13 \cdot 2$ & $8 \cdot 1$ & $10 \cdot 7$ & $12 \cdot 7$ & 0.45 & $19 \cdot 54$ & $23 \cdot 33$ \\
\hline SD & $9 \cdot 56$ & 6.96 & $7 \cdot 70$ & $5 \cdot 0$ & $3 \cdot 8$ & $4 \cdot 8$ & $7 \cdot 4$ & 0.04 & $3 \cdot 51$ & 8.55 \\
\hline 12 years & & & & & & & & & & \\
\hline Mean & $46 \cdot 57$ & $152 \cdot 37$ & $67 \cdot 11$ & $13 \cdot 8$ & $9 \cdot 9$ & $10 \cdot 9$ & $13 \cdot 2$ & 0.44 & $19 \cdot 97$ & $25 \cdot 85$ \\
\hline SD & $9 \cdot 79$ & $6 \cdot 62$ & $8 \cdot 44$ & $5 \cdot 3$ & $3 \cdot 7$ & $4 \cdot 6$ & $6 \cdot 8$ & 0.05 & $3 \cdot 53$ & 4.93 \\
\hline 13 years & & & & & & & & & & \\
\hline Mean & $50 \cdot 27$ & $155 \cdot 84$ & $68 \cdot 18$ & $14 \cdot 1$ & $9 \cdot 7$ & $11 \cdot 3$ & $13 \cdot 4$ & 0.43 & $20 \cdot 65$ & $26 \cdot 30$ \\
\hline SD & $9 \cdot 41$ & $6 \cdot 96$ & $7 \cdot 61$ & $5 \cdot 0$ & $3 \cdot 2$ & $4 \cdot 9$ & $5 \cdot 8$ & 0.04 & $3 \cdot 24$ & $4 \cdot 71$ \\
\hline 14 years & & & & & & & & & & \\
\hline Mean & $53 \cdot 12$ & $159 \cdot 60$ & $69 \cdot 35$ & $14 \cdot 7$ & $10 \cdot 3$ & $11 \cdot 6$ & $14 \cdot 7$ & 0.43 & $20 \cdot 83$ & $27 \cdot 04$ \\
\hline SD & $9 \cdot 14$ & $5 \cdot 98$ & $7 \cdot 75$ & 4.9 & $3 \cdot 5$ & $5 \cdot 4$ & $6 \cdot 9$ & 0.04 & $3 \cdot 30$ & $4 \cdot 39$ \\
\hline ANOVA & $\begin{array}{l}F=88.2 \\
P<0.001\end{array}$ & $\begin{array}{c}F=222 \cdot 1 \\
P<0.001\end{array}$ & $\begin{array}{l}F=23.99 \\
P<0.001\end{array}$ & $\begin{array}{l}F=5.93 \\
P<0.001\end{array}$ & $\begin{array}{l}F=4.91 \\
P<0.001\end{array}$ & $\begin{array}{l}F=7.70 \\
P<0.001\end{array}$ & $\begin{array}{l}F=9.55 \\
P<0.001\end{array}$ & NS & $\begin{array}{l}F=17.60 \\
P<0.001\end{array}$ & $\begin{array}{l}F=24.9 \\
P<0.001\end{array}$ \\
\hline
\end{tabular}

WC, waist circumference; TS, triceps skinfold; BS, biceps skinfold; SBS, subscapular skinfold; SPS, suprailiac skinfold; WtHR, waist-to-height ratio; \%BF, percentage body fat.

between WtHR and relative adiposity as deduced from the observed odds ratio for the categories of overweight $(\% \mathrm{BF} \geq \mathrm{P} 90: \mathrm{OR}=1 \cdot 76, P<0 \cdot 001)$ and obesity $(\% \mathrm{BF} \geq \mathrm{P} 97$ : $\mathrm{OR}=4 \cdot 78, P<0 \cdot 001)$.
The equations obtained from the regression analysis (Table 4) allow for \%BF estimation from WtHR. As deduced from the slope values and determination coefficients $\left(R^{2}\right)$, the model adjustment was better in the masculine series. 
Table 2 WtHR according to nutritional status category; boys and girls aged 6-14 years, Madrid, Spain, 2007-2008

\begin{tabular}{|c|c|c|c|c|c|c|c|c|}
\hline & \multicolumn{4}{|c|}{ Boys (n 1165) } & \multicolumn{4}{|c|}{ Girls (n 1158) } \\
\hline & $n$ & $\%$ & Mean & SD & $n$ & $\%$ & Mean & SD \\
\hline Underweight & 57 & $4 \cdot 89$ & 0.41 & 0.03 & 63 & $5 \cdot 44$ & $0 \cdot 41$ & 0.04 \\
\hline Adequate weight & 756 & $64 \cdot 89$ & 0.42 & 0.03 & 826 & $71 \cdot 33$ & $0 \cdot 42$ & 0.03 \\
\hline Overweight & 210 & 18.03 & 0.48 & 0.04 & 176 & $15 \cdot 20$ & 0.50 & 0.03 \\
\hline Obese & 142 & $12 \cdot 19$ & 0.52 & 0.05 & 93 & $8 \cdot 03$ & 0.53 & 0.03 \\
\hline ANOVA & \multicolumn{4}{|c|}{$\begin{array}{c}F=11.9 \\
P<0.001\end{array}$} & & & \multicolumn{2}{|c|}{$\begin{array}{c}F=14.6 \\
P<0.001\end{array}$} \\
\hline
\end{tabular}

WtHR, waist-to-height ratio; $\mathrm{P}$, percentile.

Underweight: \%BF $\leq$ P10; adequate weight: \%BF $>$ P10 to $<$ P90; overweight: \% BF $\geq$ P90 to $<$ P97; obese: $\% B F \geq P 97$.

Table 3 Correlation of WC and WtHR with sum of skinfolds, BMI and \%BF; boys and girls aged 6-14 years, Madrid, Spain, 2007-2008

\begin{tabular}{|c|c|c|c|c|c|c|}
\hline & \multicolumn{2}{|c|}{ Sum of skinfolds } & \multicolumn{2}{|c|}{$\% \mathrm{BF}$} & \multicolumn{2}{|c|}{ BMI } \\
\hline & Boys & Girls & Boys & Girls & Boys & Girls \\
\hline $\begin{array}{l}\text { WC } \\
\text { WtHR }\end{array}$ & $\begin{array}{l}0 \cdot 790^{\star \star *} \\
0 \cdot 823^{\star \star \star}\end{array}$ & $0 \cdot 753^{\star \star \star}$ & $0 \cdot 721^{\star \star *}$ & $0.619^{\star}$ & $0 \cdot 843^{\star \star *}$ & $0.881^{\star \star \star *}$ \\
\hline & $0 \cdot 823^{\star \star \star}$ & $0 \cdot 812^{\star \star \star}$ & $0 \cdot 811^{\star \star \star}$ & $0 \cdot 793^{\star \star \star}$ & $0 \cdot 690^{*}$ & $0 \cdot 721^{\star \star \star}$ \\
\hline
\end{tabular}

WC, waist circumference; WtHR, waist-to-height ratio; \%BF, percentage body fat.

Correlation coefficient $(r):{ }^{*} P<0 \cdot 05,{ }^{\star \star \star} P<0.001$.

Table 4 Regression analysis results for the prediction of \%BF from WtHR; boys and girls aged 6-14 years, Madrid, Spain, 2007-2008

\begin{tabular}{|c|c|c|c|c|c|}
\hline & \multicolumn{2}{|c|}{ Non-standardized coefficients $(R)$} & \multirow{2}{*}{$\frac{\text { Standardized coefficients }\left(R^{2}\right)}{\beta}$} & \multirow[b]{2}{*}{$t$} & \multirow[b]{2}{*}{$P$} \\
\hline & $B$ & Typical error & & & \\
\hline \multicolumn{6}{|l|}{ Boys } \\
\hline Constant & $-28 \cdot 362$ & 0.396 & & $-71 \cdot 709$ & $<0.001$ \\
\hline \multirow{2}{*}{\multicolumn{6}{|c|}{$\% \mathrm{BF}=106 \cdot 50 \times \mathrm{WtHR}-28 \cdot 36$}} \\
\hline & & & & & \\
\hline Constant & $-15 \cdot 140$ & 0.537 & & $-28 \cdot 194$ & $<0.001$ \\
\hline \multicolumn{6}{|c|}{$\% \mathrm{BF}=89 \cdot 73 \times \mathrm{WtHR}-15 \cdot 14$} \\
\hline
\end{tabular}

\%BF, percentage body fat; WtHR, waist-to-height ratio.

Table 5 Contrast between \%BF obtained by the Siri equation and the estimates obtained by applying the equations derived from WtHR; boys and girls aged 6-14 years, Madrid, Spain, 2007-2008

\begin{tabular}{lcccrr}
\hline & \%BF (Siri equation) & \%BF (WtHR equation) & \%BF (Siri - WtHR) & $P$ & ICC \\
\hline Boys & & & & & \\
Mean & 19.43 & 19.57 & 0.33 & 0.70 & 0.85 \\
SD & 6.88 & 5.45 & 3.27 & \\
Girls & & & & \\
Mean & 23.81 & 24.12 & 0.64 & 0.21 & 0.79 \\
SD & 7.32 & 4.26 & 3.37 & &
\end{tabular}

\%BF, percentage body fat; WtHR, waist-to-height ratio; ICC, intra-class correlation coefficient.

With the aim of testing the validity of these, the relative adiposity values predicted by the model were compared with those obtained using the Siri equation by applying a Student's $t$ test for paired samples (Table 5). This statistical test starts with analysis of the observed differences in each individual for the adiposity variable calculated using the two methods which are being compared. The average
\%BF values estimated from WtHR were slightly higher than those obtained from skinfolds $(0.14 \mathrm{~mm}$ in boys and $0.31 \mathrm{~mm}$ in girls). The $t$ statistic highlighted this proximity, demonstrating that, for relative adiposity, there were no significant differences between the Siri ${ }^{(23)}$ expression, considered to be the standard by the SEEDO (Spanish Association for the Study of Obesity $)^{(30)}$, and the equation 
developed in this work. In addition, the ICC was 0.85 in the masculine series and 0.79 in the feminine series, which shows a high agreement between both expressions according to the scale proposed by Landis and Koch and described by Kramer and Feinstein ${ }^{(29)}$.

\section{Discussion}

Anthropometric dimensions that reflect body size (height, weight, BMI) and total or central body fat (skinfold thickness, WC) increased significantly in both sexes from 6 to 14 years of age. \%BF also varied significantly as expected during puberty. However, WtHR remained constant, suggesting that the observed increase in WC reflects a normal growth process. These results are consistent with those obtained in the 'Heart Beat' project which involved 642 American children between the ages of 8 and 18 years $^{(31)}$. They also agree with those obtained in a sample of Australian students, where it was found that WtHR correlates more strongly with sum of skinfolds or with relative adiposity than with $\mathrm{BMI}^{(19)}$. This fact confirms the stability of the WtHR index during the studied growth period and supports the proposed methodology of using WtHR as a predictor of \%BF.

A prior study carried out on a sample of young Mexicans aged between 16 and 19 years has already shown significant differences for WtHR among individuals included in the normal weight, overweight and obese categories; although it should be noted that, in all of them, the mean WtHR values obtained were slightly higher than those in the present study: 0.53 (in boys) and 0.54 (in girls) for overweight and obesity ${ }^{(32)}$. Also, in Chilean schoolchildren studied by Arnaiz et $a l^{(12)}$, the WtHR values presented were higher than those obtained here, independently of the nutritional status category. Several studies have described ethnic disparity in the normal values of WtHR in adult populations and, in a recent meta-analysis, Lee et $a l^{(33)}$ found that the optimal cut-off point for discriminating cardiometabolic risk factors ranged between 0.46 and 0.62 in different human groups. It is possible that WtHR shows certain population variability also in the paediatric age group, which has already been confirmed by other anthropometric indicators such as waist-to-hip ratio and conicity index. Analysing these characteristics, Sempei et al. ${ }^{(34)}$ and Kagawa et al. ${ }^{(35)}$ have reported differences in the ontogenetic pattern of adipose distribution among schoolchildren from Europe, Asia and Australia. Likewise, Romero-Collazos et al. ${ }^{(36)}$ found that children of Argentinean, Cuban, Mexican and Venezuelan origin, among whom there was a high indigenous component, presented a more centralized fat distribution than did Spanish children.

To date, many equations have been published for calculating body composition by anthropometry in the child and adolescent population, and their consistency is variable ${ }^{(37)}$. The majority of formulas for estimating fat percentages in children under 18 years old were elaborated with regression techniques applied to samples from populations from a determined origin and age range, as in the current work. Some of these equations estimate relative adiposity from body density ${ }^{(24,25,38,39)}$ while others do this directly by measuring various skinfolds ${ }^{(40-44)}$. Other mathematical expressions obtain fat mass or fat-free mass using factors such as weight, height and triceps skinfold ${ }^{(45,46)}$. The formula proposed in the present investigation shows a clear advantage over all of these, since it uses only height and WC for $\% \mathrm{BF}$ prediction. The two dimensions that make up the WtHR are considerably simpler than skinfold thickness, whose measurement requires more precise techniques and special equipment.

\section{Study limitations}

The strength of the present study is the gender balanced and large sample. Furthermore, the anthropometry for estimating total and relative adiposity was proved a reliable technique as deduced from the low TEM. As indicated in the Methodology, the sample was taken in schools and colleges of the city of Madrid, so we do not have individuals from rural areas. Moreover, no information is available concerning the level of income to properly define socio-economic status. Also we do not have data on dietary and exercise habits, factors that modulate growth and levels of adiposity. This situation can limit the scope of the results, although the purpose of the study was not to analyse the association between environmental factors and anthropometry, but to determine the association between two types of anthropometric indicators to establish a predictive model. It should be noted that the design of the study is cross-sectional and the sample is homogeneous; therefore, the developed equations may not be generalizable to other ethnically diverse populations.

\section{Conclusions}

WtHR is effective for predicting fat percentage in 6- to 14-year-olds. The equations developed through regression analysis in order to estimate \%BF from WtHR show high concordance with the Siri method and obtain comparable results. The use of the expressions obtained here can simplify the diagnosis of obesity in the paediatric age group.

\section{Acknowledgements}

Sources of funding: The study was supported by Ministry of Education and Science of the Spanish Government (Project BOS/GGL-2005-03752). Ethics: Ethical approval was not required. Conflicts of interest: The authors 
declare that they have no conflict of interest. Authors contributions: All authors were involved in study design, anthropometric measurements, statistical analysis and interpretation, and preparation of the paper.

\section{References}

1. Carmenate M, Marrodán MD, Mesa MS et al. (2007) Obesidad y circunferencia de la cintura en adolescentes madrileños. Rev Cub Salud Publica 33, 3.

2. Gorostiza-Langa A, Román Busto JM \& Marrodán MD (2008) Indicadores antropométricos en adolescentes españoles. Zainak Cuad Antropol 30, 85-95.

3. Steiberg J \& Daniels SR (2003) Obesity, insulin resistance, diabetes and cardiovascular risk in children: an American Heart Association Scientific Statement from the Atherosclerosis, Hypertension, and Obesity in the Young Committee and the Diabetes Committee. Circulation 107, 1448-1453.

4. Barba G, Sieri S, Dello Russo M et al. (2012) Glycaemic index and body fat distribution in children: the results of the ARCA Project. Nutr Metab Cardiovasc Dis 22, 28-34.

5. Benjumea MV, Molina DI \& Arbeláez PE (2008) Circunferencia de la cintura en niños y escolares manizaleños de 1 a 16 años. Rev Colombiana Cardiol 15, 23-34.

6. Hirscher V, Molinari C \& Maccallini G (2010) Comparison of different anthropometric indices for identifying dyslipemia in school children. Clin Biochem 44, 659-664.

7. Xiong F, Garnett SP, Cowell CT et al. (2010) Waist circumference and waist-to-height ratio in Han Chinese children living in Chongqing, south-west China. Public Health Nutr 14, 20-26.

8. Fernández JR, Redden DT, Pietrobelli A et al. (2004) Waist circumference percentiles in nationally representative samples of African-American, European-American, and Mexican-American children and adolescents. J Pediatr 145, 439-444.

9. Kromeyer-Hauschild K, Dortschy R, Stolzenberg H et al. (2011) Nationally representative waist circumference percentiles in German adolescents aged 11.0-18.0 years. Int J Pediatr Obes 6, 9-37.

10. Mihanoupulos N, Holubkob R, Young P et al. (2010) Expected changes in clinical measures of adiposity during puberty. J Adolesc Health 47, 360-366.

11. Freedman DS, Dietz WH, Srinivasan SR et al. (2009) Risk factors and adult body mass index among overweight children: the Bogalusa Heart Study. Pediatrics 123, 750-757.

12. Arnaiz P, Marín A, Pino F et al. (2010) Índice cintura/talla y agregación de componentes cardiometabólicos en niños y adolescentes de Santiago. Rev Med Chile 138, 1378-1385.

13. Schwandt P, Bertsch P \& Hass GM (2010) Anthropometric screening for silent cardiovascular risk factors in adolescents: the PEP Family Heart Study. Atherosclerosis 211 , 667-671.

14. Di Bonito P, Capaldo B, Forziato C et al. (2008) Central adiposity and left ventricular mass in obese children. Nutr Metab Cardiovasc Dis 18, 613-617.

15. Rend ME, Escobedo MA, Fajardo L et al. (2009) Asociación entre circunferencia de la cintura e índice cintura-talla con el riesgo de depresión en adolescentes. In Memorias XXV Congreso Nacional de Investigación Biomédica, Facultad de Medicina, Universidad Autónoma de Nuevo León, México. http://www.congresobiomedico.org.mx/ memorias2009/htm/1097/85.htm (accessed March 2013).

16. Cristo Rodríguez-Pérez M, Cabrera de León A, AguirreJaime A et al. (2010) El cociente perímetro abdominal/ estatura como índice predictor de riesgo cardiovascular y diabetes. Med Clin (Barc) 134, 386-391.
17. Hsieh SD, Ashwell M, Muto T et al. (2010) Urgency of reassessment of role of obesity indices for metabolic risks. Metabolism 59, 834-840.

18. Setton D (2010) El índice cintura para la talla predice mejor el aumento de riesgo cardiovascular en niños con sobrepeso. Evid Act Pract Ambul 13, 1-15.

19. Nambiar S, Hughes I \& Davies P (2010) Developing waistto-height ratio cut-offs to define overweight and obesity in children and adolescents. Public Health Nutr 13, 1566-1574.

20. Marrodán MD, Martínez-Álvarez JR, González-Montero de Espinosa M et al. (2012) Diagnostic accuracy of waist to height ratio in screening of overweight and infant obesity. Med Clin (Barc) (Epublication ahead of print version).

21. World Medical Association (2004) World Medical Association Declaration of Helsinki. Ethical Principles for Medical Research Involving Human Subjects. http://www.wma.net/ e/policy/pdf/17c.pdf (accessed March 2013).

22. Weiner JS \& Lourie JA (1981) Practical Human Biology. London: Academic Press.

23. Siri WE (1961) Body composition from fluid spaces and density. In Techniques for Measuring Body Composition [J Brozeck and A Henschel, editors], pp. 000-000. Washington, DC: National Academy of Sciences.

24. Brook CGD (1971) Determination of body composition of children from skinfold measurements. Arch Dis Child $\mathbf{4 6}$, 182-184.

25. Durnin JV \& Rahaman MM (1967) The assessment of the amount of fat in the human body from measurements of skinfold thickness. Br J Nutr 21, 681-689.

26. Marrodán MD, Mesa MS, Alba JA et al. (2006) Diagnosis de la obesidad: actualización de criterios y su validez clínica y poblacional. An Pediatr (Barc) 65, 5-14.

27. Stewart A, Marfell-Jones M, Olds $\mathrm{T}$ et al. (2011) International Standards for Anthropometric Assessment. Lower Hutt: International Society for Advancement of Kinanthropometry.

28. Pederson D \& Gore C (2000) Error en la medición antropométrica. In Antropometrica, pp. 61-70 [K Norton and T Olds, editors]. Rosario: Biosystem.

29. Kramer MS \& Feinstein AR (1981) Clinical biostatistics. LIV. The biostatistics of concordance. Clin Pharmacol 1, 111-123.

30. Sociedad Española para el Estudio de la Obesidad (1996) Consenso español 1995 para la evaluación de la obesidad y para la realización de estudios epidemiológicos. Med Clin (Barc) 107, 782-787.

31. Eissa MN, Dai S, Mihalopoulos NL et al. (2009) Trajectories of fat mass index, fat free-mass index, and waist circumference in children: Project HeartBeat! Am J Prev Med 37, 34-39.

32. Ortiz-Pérez H, Molina-Frechero N \& Castañeda-Castaneira E (2010) Indicadores antropométricos de sobrepeso y obesidad en adolescentes. An Mex Pediatr 77, 241-247.

33. Lee CM, Huxley RR, Wildman RP et al. (2008) Indices of abdominal obesity are better discriminators of cardiovascular risk factors than BMI: a meta-analysis. $J$ Clin Epidemiol 61, 646-653.

34. Sempei MA, Novo NF, Juliano Y et al. (2008) Anthropometry and body composition in ethnic Japanese and Caucasian adolescent boys. Pediatr Int 1, 679-686.

35. Kagawa M, Byrne NM, King NA et al. (2009) Ethnic differences in body composition and anthropometric characteristics in Australian Caucasian and urban Indigenous children. Br J Nutr 102, 938-946.

36. Romero-Collazos JF, Marrodán MD, Mesa MS et al. (2010) Grasa corporal y distribución de la adiposidad en escolares latinoamericanos y españoles. In Diversidad Humana $y$ Antropología Aplicada, pp. 221-227 [E Gutierrez-Redomero, A Sánchez-Andrés and V Galera Olmo, editors]. Alcalá de Henares: Editorial Universidad de Alcalá de Henares. 
37. Marrodán MD, Pérez BM, Morales E et al. (2009) Contraste y concordancia entre ecuaciones de composición corporal en edad pediátrica: aplicación en población española y venezolana. Nutr Clin Diet Hosp 29, 4-11.

38. Lohman JG, Slaughter MH, Boileau RA et al. (1986) Applicability of body composition techniques and constants for children and youths. Exerc Sports Sci Rev 14, 325-357.

39. Deurenberg J, Pieters L \& Hautvast JA (1990) The assessment of the body fat percentage by skinfold thickness measurements in childhood and young adolescence. $\mathrm{Br} \mathrm{J}$ Nutr 63, 293-303.

40. Johnston JL, Leong MS, Checkland EG et al. (1988) Body fat assessed from body density and estimated from skinfold thickness in normal children and children with cystic fibrosis. Am J Clin Nutr 48, 1362-1366.

41. Parizkova J (1995) Changes in approach to the measurement of body composition. In Body Composition Techniques in
Health and Disease, pp. 222-239 [PSW Davies and TJ Cole, editors]. Cambridge: Cambridge University Press.

42. Slaughter MH, Lohman TG, Boileau RA et al. (1988) Skinfolds equations for estimation of body fatness in children and youth. Hum Biol 60, 709-723.

43. Bray GA, De Lany JP, Harsha DW et al. (2001) Evaluation of body fat in fatter and leaner 10-y-old African American and white children: the Baton Rouge Children's Study. Am J Clin Nutr 73, 687-702.

44. Bray GA, DeLany JP, Volaufova J et al. (2002) Prediction of body fat in 12-y-old African American and white children: evaluation of methods. Am J Clin Nutr 76, 980-990.

45. Johnston JL (1982) Relationships between body composition and anthropometry. Hum Biol 54, 221-245.

46. Ellis JK (1997) Body composition of a young, multiethnic female population. Am J Clin Nutr 65, 724-731. 